\title{
Creating Dynamic Practices: NJCU's Programs for Student Success
}

\author{
Jessica Accurso-Salguero ${ }^{1 *}$, Cinthia Diaz ${ }^{2}$ and Sarah Vandermark ${ }^{3}$ \\ ${ }^{1}$ Seton hall university, USA \\ ${ }^{2} N j c u$ university, USA \\ ${ }^{3}$ Montclair State University, USA
}

*Corresponding author: Jessica Accurso-Salguero, Seton hall university, USA.

Received Date: February 21, 2019

Published Date: March 25, 2019

\begin{abstract}
This paper will provide an overview of New Jersey City University's (NJCU) retention initiative programs for low-income, firstyear minority students. The programs provide students with advising, peer-mentoring, college transition workshops, outreach campaigns targeting at-risk student groups, and financial assistance. NJCU's intrusive advising, serves as a catalyst for connecting students to resources on campus. This paper provides information on the implementation of successful programs and newer programs of promise, such as the Orientation to College and Peer Advisor Liaisons programs. NJCU's ASCEND Summer Bridge Program, which was developed to assist students who were at a disadvantage academically in entering a four-year college and provides academic preparation, holistic support, advisement, mentoring, orientation to college for first time, full-time freshmen support, and campus engagement. The work conducted at NJCU successfully provides for the needs of students now and in the future.
\end{abstract}

\section{Introduction}

Approximately one-third of all college students in the United States are low-income, first-year students [1]. Studies show that low-income, first-year students frequently underperform in secondary school and consequently college [2]. A significant percentage of these college students are unprepared for collegelevel work in at least one of the following areas: reading, writing, or mathematics [3]. Research indicates that college bound students with weak academic skills are often required to complete at least two semesters of developmental coursework before enrolling fulltime solely in college-level courses [4,5]. Over the past five years, at NJCU, approximately $87 \%$ of students needed to enroll in at least one developmental English or Math course, and 69\% of these students needed to enroll in two developmental courses in English and Mathematics. With this in mind, it is imperative to understand that student enrollment, retention, and graduation depend on access and the level of institutional support provided [6].

Low-income, first-year students who engage in heightened interactions with individuals on campus as well as have access to academic, cultural, social, and personal means to engage with teachers and peers increases their academic success and retention in college [2]. NJCU has begun (within the last 5 years) and contributes to its largely low-income, first-year students by providing mentorship, college transition workshops, outreach campaigns targeting at-risk student groups, and emergency financial assistance. Through campus-wide data-driven processes, NJCU has made a commitment to student success as one of its highest institutional priorities as evidenced in the 2013-2018 Strategic Plan [7]. NJCU's commitment is supported in the development of several programs, many that serve first-time, full-time freshmen who have been placed in at least one developmental course.

Additionally, NJCU's programs support the general student population who work part-time or full-time, live off-campus, and support families; a common characteristic of first-time, full-time students $[8,9]$. The intention of NJCU is to support low-income, firstyear students who experience limited opportunities for academic success. The following paper presents a brief history of NJCU, the types of programs that are available to NJCU students, specifically programs related to advisement and Summer Bridge, and future 
intentions to further the NJCU mission and create student success for all students.

\section{New Jersey City University Background}

The history of NJCU dates back to 1929 when it was first named New Jersey State Normal School at Jersey City. The school was later renamed the New Jersey State Teachers College at Jersey City in 1935 and Jersey City State College in 1958 before assuming its current role and name in 1998 when it was approved for university status. At that time, The College of Arts and Sciences, The College of Education, and The College of Professional Studies were established and in 2002, NJCU and Brookdale Community College located in Wall, NJ, initiated a "Communiversity" partnership which offered bachelor and master's degree completion programs for residents in central and southern New Jersey. Later, in 2007, NJCU opened a facility for graduate business programs in Jersey City's waterfront financial district and in 2015, the NJCU School of Business opened.

Currently, NJCU enrolls 8,500 students, of which 6,600 are undergraduates. NJCU host 4 colleges, offers 43 undergraduate and 30 graduate degrees, and is both a Hispanic Serving Institution (HIS) and a Minority Serving Institution (MSI). The demographics of NJCU are made up of a student body that is 35\% Hispanic, $21 \%$ African American, 23\% White, and 8\% Asian, and as many as $95 \%$ of students are commuters. The average household income is $\$ 42,000$, and Pell eligible students stand at $84 \%$ overall. To date, NJCU engages in significant institutional wide investments in student success, has invested $\$ 1.5$ million in institutional financial aid and scholarships, $\$ 500 \mathrm{k}$ in student focused programming, $\$ 400 \mathrm{k}$ in improved systems and technology, supported 10 new fulltime administrative positions, and has staff that spends countless hours in meetings and serving on committees.

\section{Programs Offered}

An effective strategy in influencing undergraduate retention and academic achievement has been through increasing student interactions with faculty, staff, advisors, peers, and administrators [10]. Additionally, recent retention research stresses crossdepartmental institutional responsibility for retention through a wide-range of programs [11]. NJCU institutes numerous outreach programs and campaigns and takes a holistic approach to undergraduate retention, which includes all members of the campus. Furthermore, NJCU promotes retention and student success through offering financial literacy workshops, pairing students with one financial aid counselor, using peer to peer mentorship, increasing faculty participation, promoting academic advisor targeted outreach, creating socially engaging activities, bridging the curricular and extra-curricular, and offering supplemental instruction and tutoring. NJCU's focus on meeting students where they are has allowed for an inclusive campus climate bolstered by peer mentoring, an institution of student support through financial assistance and awareness, university advisement, and the Summer Bridge Program.

\section{Campus Climate}

The lack of diversity in a student body, faculty, and institutional leadership negatively affects the undergraduate retention of minority students [5]. For underrepresented students, it is important to remove cultural barriers so that students can connect to the larger campus community [12]. Social support networks and student organizations play an important role in helping students feel they belong within an institution [6]. Positive interactions between students and faculty were identified as a major reason contributing to the retention of students [5]. When Latino, Black, and other minority students perceive their campuses as being ethnically diverse they are much more likely to be retained. Conversely, minority students who reported more discrimination or acts of racial bigotry on campus had lower academic performance, are less satisfied with their academic and intellectual development, and have less commitment to the institution or their own academic achievement [5], indirectly impacting the student's decision to persist. However, in a campus environment that actively encourages tolerance and acceptance and appropriately engages students in academic and social discourse, students develop a sense they belong and are accepted [5].

Students who participate in community service activities, religious clubs, student government, sports teams, tutoring programs, and interact with peers and faculty outside of the classroom, were found to have higher sense of belonging [12]. Interactions students have with individuals on campus can influence a students' sense of connectedness to the institution, as well as their ability to navigate the campus culture, and succeed academically. Therefore, offering accessible academic, personal, and social support services on campus is a key approach to improving undergraduate retention. Programs and initiatives designed to support undergraduate retention address both formal and informal student experiences inside and outside of the classroom and at NJCU the focus on welcoming diversity and including all students regardless of religion, skin color, ethnicity, sexual identity, or any other characteristic creates a climate of acceptance.

\section{Peer Mentoring}

Peer mentoring is one of the most effective methods to increase student retention, graduation rates, and cross-cultural understanding of undergraduate students [13]. The goal of NJCU's peer mentoring efforts is to foster academic success and enhance the psychosocial functioning of new students as they transition from high school to a college environment. Peer mentoring was first offered in the fall of 2015 to all minority first-time freshmen during the first week of the academic year, and participation was voluntary.

The first cohort of peer mentors were selected from a pool of minority candidates who were in their sophomore year or beyond, had a cumulative grade point average of 3.0 or better, and who were involved in at least one student organization or club.

Today, and to successfully engage in peer mentoring, candidates are interviewed by a coordinator and selected based on their commitment to the institution and their knowledge of how to navigate the campus, both socially and administratively. Peer mentors are assigned a caseload of twenty mentees and are paid a stipend for the semester in which they mentor. Incoming students and families begin meeting mentors from November and beyond 
at which time NJCU's financial workshops begin. NJCU's Peer Mentoring Program requires students to meet with their mentees three to four times a semester and to check-in with their mentees through phone calls or email throughout the academic year. The list of topics that peer mentors use in meetings with a mentee include reviewing academic support services that are available, introducing mentees to student activities and organizations, and ensuring mentees are not experiencing academic or social issues adjusting to college. Peer mentors also promote university resources, field questions, and support students transitioning to college. Incoming students are introduced to campus life, tutoring services, the health and wellness center, the counseling center, the student government and various clubs. Peer Mentors meet with their students individually and in groups during the summer as well as throughout the academic school year. Peer Mentorship, coupled with intentional family programs, and culturally relevant activities in and outside of the classroom are essential in creating a healthy campus climate for our students.

\section{Financial Assistance and Awareness}

It has been well established that working while attending college, paying for tuition through loans or grants, and having financial need are factors that affect undergraduate retention [14]. Typically, if there exists a gap in financial support, even after institutional and family contributions, students tend to register part-time, work longer hours, or live off-campus, all of which have a negative impact on retention [12]. Financial aid and support matters to all students, especially Latino, Black, and other minority students as low-income minority students who receive financial aid are more likely to persist than their counterparts who did not receive financial aid [9]. These findings were particularly revealing in studies involving first-year Latino and Black students. For this student population, the decision to attend or persist in college directly relates to several factors, among them understanding how to complete a FAFSA.

In the 2016-2017 school year, fall to spring first time, full-time retention was at $37 \%$ due to $90 \%$ of the students not completing their FAFSAs, the majority of these students being Latino and Black. To support students in need, NJCU instituted a program in which the College was able to offer financial aid, financial literacy, and academic skills workshops monthly during the academic year. Professional staff members from enrollment management and student affairs conducted the workshops, and attending the workshops was voluntary and made available to all first-time freshmen students. Evidence of these initiatives was apparent in that last year's cohort persisted by more than $87 \%$ and registered for the spring semester because their FAFSA's were complete.

Furthermore, in reviewing and reaching out to first-time freshmen who have an outstanding tuition balance, we found that many had unmet financial need, even after receiving federal and state aid and loans. For the students who were unable to cover the cost of tuition and books out of pocket, the University allocated individual emergency grants of up to $\$ 2,000$ to cover an outstanding tuition balance. A financial aid committee, based on a review of a student's financial aid profile and any proof of extenuating circumstances a student or their family could provide, and award these additional grants. In the first year of implementation, twenty-one grants were awarded, with the average award being approximately $\$ 500$. For first-time freshmen who had administrative holds on their records, ranging from immunizations, financial aid issues, and outstanding balances, financial literacy, and aid options were addressed student by student through the support of one-on-one sessions with assigned financial aid advisors. Financial support programs and initiatives only make up part of the work being conducted at NJCU to offer support to all students, and especially low-income, firstyear students.

\section{University Advisement}

NJCU's Advisement Center serves as a catalyst for connecting students to resources on campus. An additional resource for incoming freshmen, NJCU implemented intrusive advising in the fall of 2016. The priorities of intrusive advising are a focus on retention and graduation, academic support, intensified academic advisement, accountability, supervision, and consistency. To date, we have connected more than $75 \%$ of our students to advising sessions, and $50 \%$ to our tutorial services, as well as workshops hosted by our advisors. These interventions have increased retention by $65 \%$ in good standing for full-time freshmen. Staff members or peer mentors, depending on the issue, reach out through email, text, or by phone to connect with students to assist in resolving an issue or to provide any assistance needed. Furthermore, NJCU's advisors have now started teaching Orientation to College (OTC) courses, tracking students by cohort, holding personalized advisement sessions, and creating relationships with students by "meeting them where they are". By creating a dynamic intrusive advisement program at NJCU, an atmosphere geared toward student success is created. Along with the success of advisement at NJCU, the Summer Bridge Program has been instrumental in serving low-income, firstyear students.

\section{Summer Bridge Program}

During the winter of 2014, the President of NJCU hosted a university wide retreat focused on student success. During this retreat, the University identified the need for cross-divisional efforts to improve student success and that the needs of minority students, especially Latinos, are uniquely different. In 2015, NJCU created Achieving Success by Cultivating Excellence and Nurturing Discovery (ASCEND). A significant percentage of college students are unprepared for college-level work in reading, writing, or mathematics and Summer Bridge programs help mitigate these occurrences [5,15].

The student demographics for NJCU's ASCEND Program students are as follows: $100 \%$ of these students apply for federal aid, $100 \%$ are part of underrepresented minorities, $80 \%$ have some level of unmet need, 76\% come from household incomes of less than $\$ 60,000$, and approximately $90 \%$ are PELL eligible and require developmental support. The ASCEND intensive sevenweek academic preparation and college orientation program was designed to help students advance at least one level by taking developmental summer courses. Expediting the timeframe when students enroll in full semesters of college-level courses after 
high school increases the likelihood that students complete. Each summer, approximately 100 students participate in the ASCEND Summer Bridge Program at NJCU and bridge the "summer learning gap" in an innovative way that helps students' develop and integrate their academic, physical, social, and emotional well-being as well as environmental awareness and stewardship principles.

Although the ASCEND Summer Bridge Program started slowly and the first year's 2015 retention rate from fall to fall was $41 \%$, the success of the program grew and the second year had a success rate of $44 \%$, followed by a third year (2017) success rate of $69 \%$. Summer 2017, 100 students successfully completed the program, 43 students tested out of developmental math, and 10 students increased their scores by at least 10 points. At the conclusion of the program in 2017, more than half of the students tested out of developmental classes and the enrollment overview in Table 1 below supports these numbers (Table 1). The ASCEND Summer Bridge Program's primary components are academic preparation, academic support, academic advising, peer mentoring, orientation to college for first time, full-time freshmen, and campus engagement activities. The Program promotes peer mentorship, daily workshops that promote self-efficacy, relationship with faculty, intramural sports, and individual and group guidance counseling. Peer mentors successfully facilitate tutoring, social engagement with clubs and organizations on campus, assist with financial aid, advisement, and registration. Additional goals of the NJCU ASCEND Summer Bridge Program are to develop and strengthen students' connections with advisors, faculty, and staff to provide students with knowledge critical to success in college (e.g. study skills, time management, and campus life), and enhance students' sense of belonging. Additionally, advisors teach Orientation to College courses, track students by cohort, hold personalized advisement sessions, and create relationships with students by meeting them where they are. Advisors focus on giving students an opportunity to build relationships with students, facilitate workshops, engage in personalized one on ones, and track and assist students throughout the academic school year. Given the significant challenges inherent to any Summer Bridge Program, ASCEND has created a positive first-year experience for NJCU students.

Table 1: Summer Bridge Enrollment from 2015 through 2017.

\begin{tabular}{|c|c|c|c|c|c|}
\hline \multicolumn{5}{|c|}{ Summer Bridge Program Enrollment Overview } & \\
\hline Cohort & $\begin{array}{c}\text { Student } \\
\text { Headcount }\end{array}$ & Registered & $\begin{array}{c}\text { Not } \\
\text { Registered }\end{array}$ & \% Rate & $\begin{array}{c}\text { Year } \\
\text { Rate }\end{array}$ \\
\hline 2015 & 69 & 28 & 41 & $41 \%$ & 1 YR \\
\hline 2016 & 79 & 35 & 44 & $44 \%$ & 1 YR \\
\hline 2017 & 100 & 69 & 31 & $69 \%$ & 1 YR \\
\hline
\end{tabular}

\section{Methodology and Results}

Using a mix of methods, such as regression analysis, cohort tracking, predictive analytics, focus groups, T-tests, and Chi-Square analysis, NJCU has been able to effectively track the success of its programs as outlined in Table 2 and Figure 1 below. Through the various initiatives outlined above, NJCU has been able to not only increase the first-year retention rate but has also helped at-risk, remedial, and special cohort students persist (Table 2) (Figure 1).
Table 2: Methodology for Tracking Student Success and Corresponding Impact.

\begin{tabular}{|c|c|c|}
\hline Program/Initiative & Assessment Method & Impact \\
\hline $\begin{array}{c}\text { Increased institutional } \\
\text { aid }\end{array}$ & Regression analysis & $\begin{array}{c}\text { Improved retention } \\
\text { for first-year freshmen }\end{array}$ \\
\hline $\begin{array}{c}\text { Summer Bridge } \\
\text { Student Retention } \\
\text { Office }\end{array}$ & $\begin{array}{c}\text { Cohort tracking } \\
\text { Pocus groups }\end{array}$ & $\begin{array}{c}\text { Improved progression } \\
\text { for special admits }\end{array}$ \\
\hline $\begin{array}{c}\text { Freshmen block } \\
\text { scheduling }\end{array}$ & T-tests & $\begin{array}{c}\text { Improved retention } \\
\text { for first-year freshmen }\end{array}$ \\
\hline $\begin{array}{c}\text { Advisement } \\
\text { students in remedial } \\
\text { courses }\end{array}$ \\
\hline
\end{tabular}

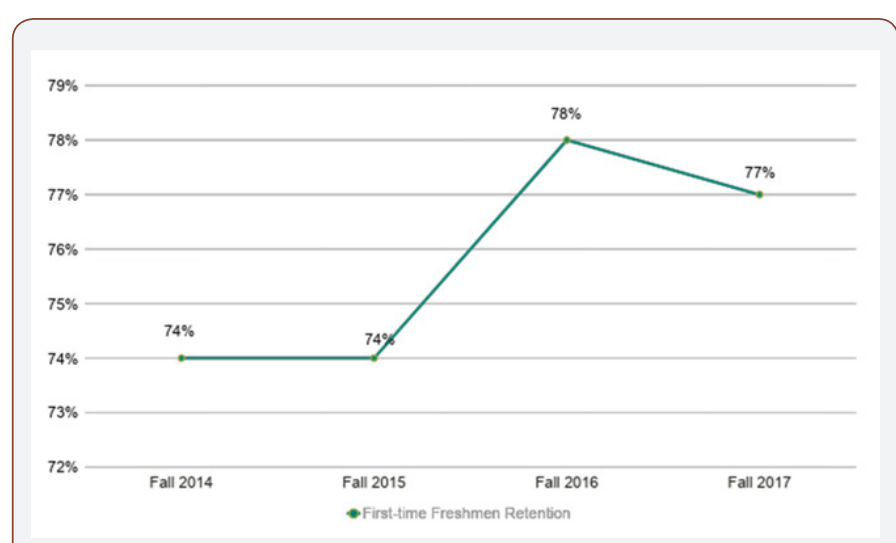

Figure 1: Fall 2014 through Fall 2017 Demonstration of student success.

\section{Looking Toward the Future}

As reiterated throughout this study, many low-income, firstyear students at NJCU are not prepared for college-level work. First-year performance often determines whether students decide to continue, and poor academic self-efficacy and self-doubt lead to drop out. At NJCU, outcome metrics include enrollment trends, pretest and post-test assessments, fall placement, student engagement, fall-to-fall retention rate, first term GPAs, first year cumulative GPAs, first year degree credit accumulation, and graduation rates. From these findings, NJCU continues to implement new programs, such as the Integration of Advisement, Block Scheduling, Orientation to College (OTC) and Peer Advisor Liaisons (PALs) programs and is experiencing significant success. Each member of the NJCU community is personally dedicated to and accountable for ensuring all students receive a high-quality education and a first-rate experience that leads to timely graduation with minimal debt, an academically rich degree, and a meaningful future upon graduation. With the unique approach of including the family members of students through culturally relevant outreach, including office staff (in some cases) with at least five Spanish-speaking individuals, and the ability to share a common culture, NJCU is on the cutting edge of student retention and success in a culturally diverse area. NJCU's dedication to student success, a reflection of a 2013-2018 Strategic Plan [7] is a reality and a guidepost for other colleges and universities serving low-income, first-year students. 


\section{Acknowledgement}

None.

\section{Conflict of Interest}

None.

\section{References}

1. Morest VS (2013) From access to opportunity: The evolving social roles of community colleges. The American Sociologist 44(4): 319-328.

2. Tinto V (2015) Through the eyes of students. Journal of College Student Retention: Research Theory \& Practice.

3. Edgecombe ND (2011) Accelerating the academic achievement of students referred to developmental education.

4. Bailey T, Jeong DW, Cho SW (2010) Referral, enrollment, and completion in developmental education sequences in community colleges. Economics of Education Review 29(2): 255-270.

5. Crisp G, Taggart A, Nora A (2015) Undergraduate Latina/o students: A systematic review of research identifying factors contributing to academic success outcomes. Review of Educational Research 85(2): 249-274.

6. Cerezo A, Mc Whirter B (2012) A brief intervention designed to improve social awareness and skills to improve Hispanic college student retention. College Student Journal 46(4): 867-879.
7. New Jersey City University Strategic Plan 2013-2018 Working Document.

8. Chen R, DesJardins SL (2010) Investigating the impact of financial aid on student dropout risks: Racial and ethnic differences. The Journal of Higher Education 81(2): 179-208.

9. Stewart S, Lim DH, Kim J (2015) Factors influencing college persistence for first-time students. Journal of Developmental Education 38(3): 1221.

10. Braxton JM, Doyle WR, Hartley III HV, Hirschy AS, Jones WA, et al. (2013) Rethinking college student retention. John Wiley \& Sons.

11. Wilson S, Fuller R, Mykhaylichenko O (2011) Student Success in Higher Education Is Everybody's Business. California Postsecondary Education Commission Report 11-08.

12. Tinto V (2017) Reflections on student persistence. Student Success 8(2): 1-9.

13. Budge S (2006) Peer mentoring in postsecondary education: implications for research and practice. Journal of College reading and learning 37(1): 71-85.

14. Chen J, Hossler D (2017) The effects of financial aid on college success of two-year beginning nontraditional students. Research in Higher Education 58(1): 40-76.

15. Strayhorn TL (2011) Bridging the pipeline: Increasing underrepresented students' preparation for college through a summer bridge program. American Behavioral Scientist 55(2): 142-159. 